\title{
POST-MERGER RETURNS IN FRONTIER MARKETS, OR HOW WE LEARNED TO STOP WORRYING AND LOVE THE ACQUIRERS
}

\author{
Adam ZAREMBA ${ }^{1^{*}}$, Adam SZYSZKA ${ }^{2}$, Michał PŁOTNICKI ${ }^{3}$, \\ Przemysław GROBELNY ${ }^{4}$ \\ ${ }^{1}$ Dubai Business School, University of Dubai, Academic city, Dubai, UAE, P.O. Box: 14143 \\ ${ }^{1,4}$ Department of Investment and Capital Markets, Poznan University of Economics and Business, \\ Niepodleglosci 10, 61-875 Poznan, Poland \\ 2, 3 Department of Capital Markets, Collegium of World Economy, \\ SGH Warsaw School of Economics, al. Niepodleglosci 162, 02-554 Warsaw, Poland
}

Received 11 Jun 2017; accepted 27 October 2017

\begin{abstract}
This study presents the results from a comprehensive out-of-sample test of long-run returns following mergers and acquisitions (M\&As). Using a unique sample from 23 frontier markets of almost 800 transactions conducted during the years 1992 to 2016, we implement both crosssectional tests and time-series examinations based on a calendar-time portfolio approach. Contrary to evidence from developed markets, the M\&As in these frontier markets do not lead to abnormal underperformance of acquirers, regardless of whether they paid for the acquisition with cash or stock. The results are robust to many considerations, including subsample and subperiod analysis, alternative formation periods, different portfolio construction approaches.
\end{abstract}

Keywords: mergers, acquisitions, long-run returns, long-term underperformance, frontier equity markets, behavioral finance, corporate finance.

JEL Classification: G11, G12, G14, G15, G34.

\section{Introduction}

In 1998, German-based Daimler-Benz AG and U.S.-based Chrysler Corporation, two leading global car manufacturers, decided to combine their businesses in what was perceived to be a merger of equals (Casestudyinc 2008). Daimler paid 37 billion USD in a stock swap exchange and on November 17, 1998, DaimlerChrysler's joint chiefs launched global trading in the shares of the new company which, with a market capitalization of 100 billion USD, was the world's fifth-largest car maker. When ringing the Wall Street bell, the two company chiefs,

${ }^{\star}$ Corresponding author. E-mail: adam.zaremba@ue.poznan.pl 
Robert Eaton and Juergen Schrempp, presented a vision of becoming the world's third-largest car maker within only three years. The opening ceremony was broadcast on DaimlerChrysler's business TV channel to all of the 260 DaimlerChrysler plants in 25 countries so that each of the more than 400,000 workers could celebrate this special moment (Gallagher 1998). The troubles were yet to come.

This transaction was overwhelmingly endorsed by analysts optimistic about its prospects of success (Gallagher 1998). DaimlerChrysler was supposed to benefit not only from cost savings, but also from complementary product lines. Unfortunately, contrasting organizational cultures and management styles effectively hindered execution of the planned synergies. As a result, only three years after the merger, the DaimlerChrysler market cap was equal to Daimler's stand-alone market cap just before the transaction. Finally, in May 2007, DaimlerChrysler decided to dump the money-losing Chrysler unit, announcing the disposal of an 80 percent stake to a private equity firm (Isidore 2007). Eventually, DaimlerChrysler received only 1.4 billion USD for the Chrysler unit - an amount that was not even enough to cover the losses generated by the unit before the sale.

Interestingly, the Harvard Business Review in its June 2016 edition published a report claiming that, typically, between 70 and 90 percent of acquisitions end up as abysmal failures (Martin 2016). In this regard, the Daimler and Chrysler deal seems to have been unexceptional.

The objective of this study is to conduct a comprehensive out-of-sample test of alleged long-run value destruction following mergers and acquisitions (M\&As) in equity markets. The question of whether M\&A processes increase or destroy value for shareholders of the acquiring companies has greatly interested academics and market practitioners. Surprisingly, the early studies of developed markets indicated that M\&A deals lead to remarkable destruction of value in the acquirers, resulting in long-term negative post-merger abnormal returns of approximately 10\% per annum that persist up to five years (Limmack 1991; Agrawal et al. 1992; Loughran, Vijh 1997; Moelleer et al. 2005).

Our paper aims to contribute by performing a comprehensive out-of-sample examination of long-run post-merger performance. To this end, we examine the performance of acquirers from frontier markets for the years 1997 through 2016. We cover a broad range of almost 800 acquisitions conducted in 23 frontier markets from South America, Asia, Africa, and Eastern Europe. Therefore, our research can be described as out-of-sample both geographically and temporally, as the previous studies concentrated predominantly on a handful of developed markets: the United States, UK, and Canada. As far as we are aware, there is no study available that covered frontier markets. Second, our sample period starts after the sample period end points of crucial earlier studies, including Limmack (1991), Franks et al. (1991), Agrawal et al. (1992), Loughram and Vijh (1997), Mitchel and Stafford (2000), and Dube and Glascock (2006).

The rest of the paper is organized as follows. Section 1 outlines the theoretical basis for this research. Section 2 presents our data sources and sample preparation. Section 3 discusses the research methods, and section 4 presents the results. The last section presents concluding remarks. 


\section{Theoretical basis and hypothesis development}

There is rich empirical evidence indicating that mergers, on average, do not create any value for the acquiring firms and, indeed, often destroy value. Analysis of share price reaction on major stock markets in the period around takeover announcements show that target company shareholders typically experience large gains in wealth, but acquiring company shareholders do not (Jensen, Ruback, 1983; Andrade et al. 2001; Moeller et al. 2005).

However, the results are also sensitive to the method of payment. Interestingly, positive abnormal stock returns are found after cash tender offers. Bouwman et al. (2009) document that cash acquirers outperformed in the 1980s, but underperformed in later years. Also, Friedman (2006) uses a large sample covering the period from 1962 until 2000 and documents the poor post-merger performance of stock bidders contrasted to outperformance following cash acquisitions.

Although the abnormal post-merger performance has been known for more than two decades, it still poses a puzzle to the academic community and a challenge for market practitioners. As neoclassical theories predict that we should observe no systematic long-run underperformance following mergers (Mueller 1969), the potential explanations are usually provided by behavioral finance. The behavioral finance framework offers two general concepts here. First, it is assumed that managers are fully rational and the source of M\&A activity lies in the inefficient market that allows relative mispricing between the acquirer and target firms. Shleifer and Vishny (2003), Rhodes-Kropf and Viswanathan (2004), and Zaremba and Grobelny (2016) offer a misvaluation theory that implies that rational managers acting in the interest of long-term shareholders initiate acquisitions - especially paid with stock - to capitalize on temporary overvaluation of the acquirer's equity. Thus, overvaluation at the time of the transaction may result in a future reversal and long-run negative abnormal returns. The second general behavioral concept points to managerial irrationality and biases, often combined with agency problems. Examples include empire building by managers (Sudarsanam, Mahate 2006), managerial entrenchment (Shleifer, Vishny 1989), hubris and overconfidence (Roll 1986), and the managerial discretion hypothesis (Mueller 1969), to name just a few.

Besides these concepts, in this study we also suggest a new, simple explanation: we hypothesize that the long-term post-acquisition abnormal performance is a spurious phenomenon. The recent asset pricing literature has documented a cornucopia of supposed return predictive signals in equity markets. Having reviewed only the top tier papers up to the year 2013, Harvey et al. (2016) identified more than 300 such signals. Alas, most of them are likely to be false discoveries (Harvey 2017). Indeed, a few recent studies have indicated that return regularities tend to follow a sort of Murphy's Law: once uncovered, they quickly disappear; their out-of-sample performance is more than disappointing (McLean, Pontiff 2016). The big quest ahead is to separate the "wheat" anomalies from the "chaff" anomalies, and there is no better way to do this than by extensive replication and out-of-sample testing (Harvey 2017).

In fact, our hypothesis is consistent with a few recent papers that also cast doubt on the significance of the abnormal performance following M\&A deals. For instance, Mitchel and Stafford (2000), Dube and Glascock (2006), and Dutta and Jog (2009) investigated the U.S. and Canadian markets and found no significant abnormal returns following such deals. Although these replications are not entirely out-of-sample - they all examined just a few 
developed markets and the sample periods overlapped to some extent with the earlier studies - their results support our "spurious anomaly" hypothesis.

\section{Data sources and sample preparation}

Our broad equities sample encompasses 23 countries classified as frontier markets by MSCI and included in the MSCI Frontier Markets Index: Argentina, Bahrain, Bangladesh, Bulgaria, Croatia, Estonia, Jordan, Kazakhstan, Kenya, Kuwait, Lebanon, Lithuania, Mauritius, Morocco, Nigeria, Oman, Pakistan, Romania, Serbia, Slovenia, Sri Lanka, Tunisia, and Vietnam. We use accounting and price data from Bloomberg, including companies classified both as listed and delisted to minimize any potential survivorship bias. The sample period of returns runs from March 1997 to September 2016, but we also use earlier data when necessary for calculating certain variables, such as the book-to-market ratio.

We applied several static and dynamic filters. A company was included in the sample for a month $t$ when its return in month $t$ and its total capitalization at the end of month $t-1$ were both available. The sample was to contain only common stocks and only securities for which the selected frontier countries were the primary markets were included. We eliminated any company in month $t$ when at the end of month $t-1$ either its nominal share price dropped under 0.20 USD, or the total stock market capitalization sank under 10 million USD. Finally, we screened the data for suspicious returns, deleting observations with monthly returns of more than $500 \%$ or less than $-98 \%$ as these most likely came from miscalculated stock split ratios (10 observations in total). Using all eligible companies available in Bloomberg, the final sample consisted of 3,627 firms. The basic composition and the evolution of the sample are shown in Figure A1 and Table A1 in the Appendix A. ${ }^{1}$

All data were converted into USD. Also, to be consistent with the use of USD, we used the 1-month U.S. T-bill rate sourced from Kenneth R. French's data library (French 2016) as a proxy for the risk-free rate.

The sample of mergers and acquisitions includes all the acquisitions revealed in Bloomberg that were conducted by firms from our equity universe within the period from September 1992 to September 2016. We included only the acquisitions of public companies listed in the frontier markets that resulted in a change of control and only when both the ISIN number and the completion announcements date were available. In total, our sample encompassed 793 deals 345 of these were paid in cash, 98 were paid in stock, and, in the remaining cases, the type of financing was undisclosed in Bloomberg. Our sample of mergers is depicted in Figure 1.

\section{Research methods}

We start our investigations with simple monthly regressions in the style of Fama and MacBeth (1973). The univariate regressions are based on the following formula:

$$
R_{i, t}=\beta_{0}+\beta_{1} D_{i, t-k: t-1}+\varepsilon_{i, t},
$$

\footnotetext{
1 The appendices are available upon request and at http://adamzaremba.pl/.
} 
where $R_{i, t}$ is the return on factor $i$ in month $t, D_{i, t-k: t-1}$ is the dummy variable equal to unity if the company $i$ conducted an acquisition within months $t-k$ to $t-1$, and $\beta_{0}$ and $\beta_{1}$ are regression parameters. Following, for example, Moeller et al. (2005) and Andre et al. (2004), we use the completion date as the reference time for the acquisition. We calculate the variable $D_{i, t-k: t-1}$ using various approaches: we base it on the full sample of M\&As, as well as on the subsamples of acquisitions paid for with cash only or stocks only. Also, given that there is no consensus in the literature regarding how long the influence of acquisitions lasts, we consider a spectrum of different periods $k$ used in earlier studies, ranging from 12 months, used by, e.g., Dube and Glascock, (2006) to 60 months, used by, e.g., Agrawal et al. (1992) and Loughran and Vijh (1997).

We continue with time-series tests based on calendar-time portfolios. The approach was implemented for post-merger performance by Savor and $\mathrm{Lu}$ (2009) and Bouwman et al. (2009), inter alia. For a few reasons, in studies of long-run events, the calendar-time portfolio approach has more recently been preferred to the buy-and-hold return approach (BHAR) that was previously popular. First, the calendar-time portfolio approach deals with the problems of instability of pricing model parameters. Second, as pointed out by Fama (1998), the BHAR approach assumes the derivation of long-term returns from the compounding of short-term returns, which may yield excessive abnormal returns even when there is no abnormal return after the first period. Third, BHAR assumes zero correlation among event-firm returns; meanwhile, Mitchell and Stafford (2000) argued that M\&As cluster through time, leading to the cross-correlation of abnormal returns. Finally, the calendar-time portfolio approach is aligned with an investor perspective.

To implement the calendar-time portfolio approach, at the end of each month $t$ we form portfolios of firms that acquired other companies during the $k$ previous months. For robustness, we use three variants of $k$, which belong to the range of the most popular formation periods used in earlier studies: 36,48 , and 60 months. ${ }^{2}$ Also, we use two different weighting schemes: equal-weighting and capitalization-weighting.

We evaluate the performance of the calendar-time portfolios with the recent five-factor (FF5) model of Fama and French (2015):

$$
R_{i, t}=\alpha_{i}+\beta_{M K T, i} M K T_{t}+\beta_{S M B, i} S M B_{t}+\beta_{H M L, i} H M L_{t}+\beta_{W M L, i} R M W_{t}+\beta_{W M L, i} C M A_{t}+\varepsilon_{i, t},
$$

where $\beta_{M K T, i}, \beta_{S M B, i}, \beta_{H M L, i}, \beta_{R M W, i}, \beta_{C M A, i}$, and $\alpha_{i}$ are the model's estimated parameters; $\beta_{M K T, i}, \beta_{S M B, i}, \beta_{H M L, i}, \beta_{R M W, i}$, and $\beta_{C M A, i}$, are measures of exposure to $M K T_{t}$ (market risk), $S M B_{t}$ (small minus big), $H M L_{t}$ (high minus low), $R M W_{t}$ (robust minus weak), and $C M A_{t}$ (conservative minus aggressive) risk factors, respectively, and $\alpha_{i}$ represents the average abnormal return. The five factors represent the returns of a market portfolio and the performance of widely-acknowledged size, value, profitability, and investment strategies. The detailed procedure for calculating the factor returns and their basic statistical properties are reported in Tables A2 and A3 of the Appendix A, respectively.

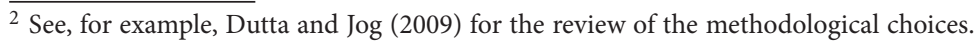




\section{Empirical results}

The results of the Fama-MacBeth analysis are depicted in Figure 1. Generally, in line with the implications of the misvaluation theory, the coefficients are predominantly negative for the companies that conducted acquisitions during the previous 18-60 months (Panel B); these are, however, very modest in terms of absolute values. The negative coefficients are much more pronounced for deals paid for with stock, amounting to approximately -0.35 for the standard 36-60-month formation period, as compared to less than half of this value for the deals paid for with cash. Nevertheless, as shown in Panel B, none of the coefficients differs significantly from zero. In other words, the Fama-MacBeth test provides no formal support of the hypothesis of Shleifer and Vishny (2003); no significant underperformance is recorded.

Table 1 reports the monthly returns on companies that conducted acquisitions during the previous 36 (Panel A) and 60 (Panel B) months (results on the 48-month formation period are displayed in Table A4 of Appendix A). A quick eyeball check leads to the conclusion that the acquirers in frontier markets are not characterized by any significant underperformance, either in the raw approach or after adjusting for the factors of the FF5 (2015) model. In fact, in the case of long-only equal-weighted portfolios, the five-factor model alphas were

Panel A: Regression coefficients

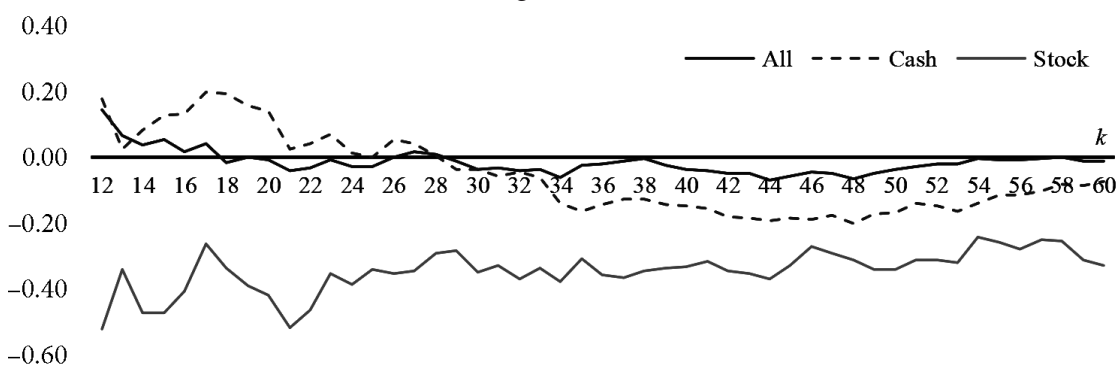

Panel B: Corresponding $t$-statistics

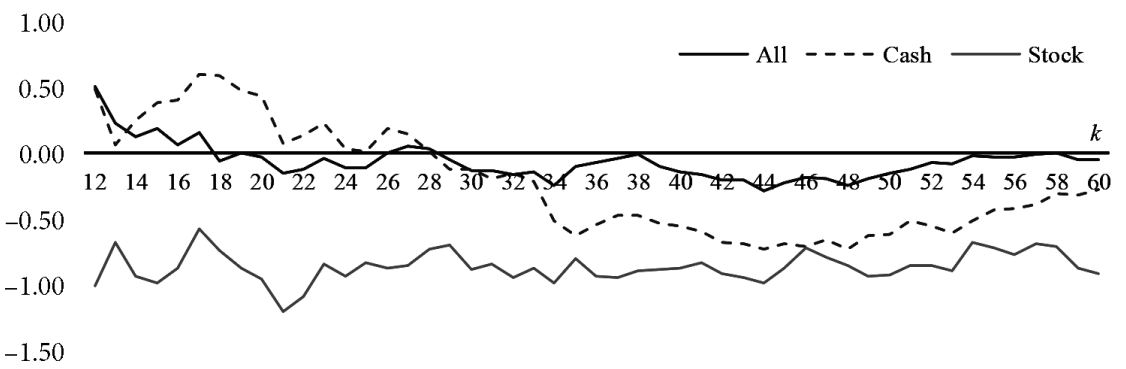

Note. The figure displays coefficients (Panel A) and corresponding $t$-statistics (Panel B) for the univariate monthly regressions in the style of Fama and MacBeth (1973) based on the formula: $R_{i, t}=\beta_{0}+\beta_{1} D_{i, t-k: t-1}+\varepsilon_{i, t}$, where $R_{i, t}$ is the return on factor $i$ in month $t, D_{i, t-k: t-1}$ is the dummy variable equal to unity if the company $i$ conducted an acquisition within months $t-k$ to $t-1$, and $\beta_{0}$ and $\beta_{1}$ are regression parameters. The figure also displays alternative definitions of $D_{i, t-k: t-1}$ referring to acquisitions paid for with cash or stock only.

Figure 1. Results of the cross-sectional Fama-MacBeth regressions 
Table 1. Performance of calendar-time portfolios of acquirers

\begin{tabular}{|c|c|c|c|c|c|c|}
\hline & \multicolumn{3}{|c|}{ Equal-weighted portfolios } & \multicolumn{3}{|c|}{ Value-weighted portfolios } \\
\hline & Acquirers & Others & $\mathrm{A}-\mathrm{O}$ & Acquirers & Others & $\mathrm{A}-\mathrm{O}$ \\
\hline \multicolumn{7}{|c|}{ Panel A: 36-month formation period } \\
\hline \multirow[t]{2}{*}{$\mathrm{R}$} & 0.35 & 0.37 & -0.02 & 0.01 & -0.12 & 0.13 \\
\hline & $(0.95)$ & $(1.45)$ & $(-0.07)$ & $(-0.02)$ & $(-0.50)$ & $(0.43)$ \\
\hline Vol & 5.50 & 3.68 & 3.92 & 6.43 & 4.56 & 4.88 \\
\hline \multirow[t]{2}{*}{$\alpha$} & $0.45^{*}$ & $0.33^{*}$ & 0.12 & 0.23 & -0.02 & 0.25 \\
\hline & $(2.14)$ & $(1.98)$ & $(0.59)$ & $(1.05)$ & $(-0.43)$ & $(0.99)$ \\
\hline \multirow[t]{2}{*}{ MKT } & $0.93^{* *}$ & $0.67^{* *}$ & $0.26^{\star *}$ & $1.01^{\star *}$ & $0.97^{\star *}$ & 0.04 \\
\hline & $(10.94)$ & $(8.53)$ & $(4.62)$ & $(13.68)$ & $(78.39)$ & $(0.46)$ \\
\hline \multirow[t]{2}{*}{ SMB } & $-0.26^{*}$ & $0.18^{\star *}$ & $-0.44^{\star \star}$ & $-0.50^{* *}$ & $0.09^{* *}$ & $-0.59^{* *}$ \\
\hline & $(-2.23)$ & $(2.81)$ & $(-5.24)$ & $(-4.11)$ & $(5.93)$ & $(-4.52)$ \\
\hline \multirow[t]{2}{*}{ HML } & 0.06 & 0.03 & 0.04 & -0.02 & 0.03 & -0.06 \\
\hline & $(0.64)$ & $(0.40)$ & $(0.50)$ & $(-0.32)$ & $(1.74)$ & $(-0.63)$ \\
\hline \multirow[t]{2}{*}{ RMW } & 0.01 & $0.08^{\star *}$ & -0.07 & -0.12 & $0.05^{\star \star}$ & $-0.16^{*}$ \\
\hline & $(0.30)$ & $(2.87)$ & $(-1.29)$ & $(-1.75)$ & $(2.69)$ & $(-1.97)$ \\
\hline \multirow[t]{2}{*}{ CMA } & -0.06 & $-0.14^{\star \star}$ & 0.07 & -0.08 & 0.00 & -0.07 \\
\hline & $(-1.03)$ & $(-4.31)$ & $(1.18)$ & $(-0.81)$ & $(-0.21)$ & $(-0.66)$ \\
\hline $\mathrm{R}^{2}$ & 0.68 & 0.68 & 0.34 & 0.70 & 0.96 & 0.21 \\
\hline \multicolumn{7}{|c|}{ Panel B: 60-month formation period } \\
\hline \multirow[t]{2}{*}{$\mathrm{R}$} & 0.39 & 0.37 & 0.02 & 0.00 & -0.10 & 0.10 \\
\hline & $(1.06)$ & $(1.44)$ & $(0.09)$ & $(-0.02)$ & $(-0.42)$ & $(0.34)$ \\
\hline Vol & 5.48 & 3.68 & 3.91 & 6.52 & 4.52 & 5.02 \\
\hline \multirow[t]{2}{*}{$\alpha$} & $0.51^{*}$ & 0.33 & 0.18 & 0.25 & -0.01 & 0.27 \\
\hline & $(2.48)$ & $(1.94)$ & $(0.89)$ & $(1.07)$ & $(-0.20)$ & $(0.96)$ \\
\hline \multirow[t]{2}{*}{ MKT } & $0.93^{\star *}$ & $0.67^{* *}$ & $0.27^{\star *}$ & $1.03^{* *}$ & $0.96^{\star *}$ & 0.07 \\
\hline & $(11.32)$ & $(8.46)$ & $(4.41)$ & (12.30) & $(59.71)$ & $(0.76)$ \\
\hline \multirow[t]{2}{*}{ SMB } & $-0.27^{\star}$ & $0.18^{* *}$ & $-0.45^{\star *}$ & $-0.47^{\star *}$ & $0.09^{\star *}$ & $-0.55^{\star *}$ \\
\hline & $(-2.20)$ & $(2.85)$ & $(-5.03)$ & $(-3.55)$ & $(4.60)$ & $(-3.75)$ \\
\hline \multirow[t]{2}{*}{ HML } & 0.06 & 0.03 & 0.03 & -0.04 & 0.04 & -0.08 \\
\hline & $(0.58)$ & $(0.42)$ & $(0.43)$ & $(-0.36)$ & $(1.88)$ & $(-0.67)$ \\
\hline \multirow[t]{2}{*}{ RMW } & 0.01 & $0.08^{* *}$ & -0.07 & -0.12 & $0.05^{*}$ & $-0.17^{\star}$ \\
\hline & $(0.23)$ & $(2.85)$ & $(-1.40)$ & $(-1.83)$ & $(2.40)$ & $(-1.96)$ \\
\hline \multirow[t]{2}{*}{ CMA } & -0.04 & $-0.14^{\star \star}$ & 0.10 & -0.02 & -0.02 & 0.01 \\
\hline & $(-0.59)$ & $(-4.43)$ & (1.45) & $(-0.16)$ & $(-1.12)$ & $(0.06)$ \\
\hline $\mathrm{R}^{2}$ & 0.69 & 0.68 & 0.36 & 0.69 & 0.95 & 0.19 \\
\hline
\end{tabular}

Note. The table reports the performance of calendar-time portfolios formed of stocks of firms that conducted acquisitions (Acquirers) during the previous 36 (Panel A) and 60 (Panel B) months. Others is a control portfolio of firms that did not conduct any acquisitions during the same period; an $A-O$ is a zero-investment portfolio which goes long (short) Acquirers (Others). $R$ is a mean monthly excess return; $\mathrm{Vol}$ is a standard deviation of monthly returns, $\alpha$ is an intercept from the five-factor model of Fama and French (2015), MKT, SMB, HML, RMW, and CMA are respective factor exposures, and $R^{2}$ is a coefficient of determination. $R, \mathrm{Vol}$, and $\alpha$ are expressed in percentage terms. The numbers in brackets are bootstrap (for $R$ ) and Newey-West (1987) adjusted (for regression coefficients) $t$-statistics. Asterisks ${ }^{*}$ and ${ }^{* *}$ indicate statistical significance at the $5 \%$ and $1 \%$ levels, respectively. 
significantly positive, but this may be due to diversification return (see Willenbrock (2011)) on a portfolio of volatile stocks from multiple low-correlated markets. Neither in the valueweighted portfolios or the long-short portfolios that go long (short), did the acquirers (other companies) exhibit any abnormal performance.

Noticeably, the performance of M\&A-based portfolios displays no clear exposure to the FF5 model's factors, including the investment factor CMA. The only exception is the size factor SMB-apparently, the acquirers are usually larger than the average company in the market.

One potential reason we do not see the post-merger long-term underperformance in frontier markets may be related to the nature of this kind of less developed segment of the capital market. We may assume that frontier markets are typically less liquid, less efficient, and have worse corporate governance (higher agency costs) than mature markets. Acquirers active in frontier markets are more likely to find a target for a takeover at a bargain price. It is also easier to enable true synergies after a takeover, especially if the target was a smaller, mismanaged firm. Hence, biases related to hubris, overconfidence, and other aspects of managerial irrationality on the side of the acquirers are more easily offset by opportunistically priced targets. In mature markets, on the other hand, it is more difficult to find attractively priced targets or to free up simple synergies. In such cases, managerial biases among acquirers are more likely to negatively affect long-term post-merger performance.

The theory of Shleifer and Vishny (2003) predicts that the underperformance of acquirers should be particularly pronounced following transactions paid in stocks. Indeed, evidence in support of this implication is provided by Bouwman, Fuller, and Nain (2009), Savor and Lu (2009), Lau and Proimos (2010), and Lin, Chou, and Cheng (2011), and this is also consistent with the visual pattern in Figure 1 of this paper. Thus, we also replicate our tests within the subsamples of deals paid for with cash only and those paid for with stocks only. The results are reported in Table 2.

Table 2. Monthly returns on calendar-time portfolios of acquirers following deals paid for with cash and stocks

\begin{tabular}{|c|c|c|c|c|c|c|}
\hline \multirow{2}{*}{} & \multicolumn{5}{|c|}{ Panel A: Payment type-cash } \\
\cline { 2 - 6 } & $\begin{array}{c}\text { 36-month } \\
\text { formation } \\
\text { period }\end{array}$ & $\begin{array}{c}\text { 48-month } \\
\text { formation } \\
\text { period }\end{array}$ & $\begin{array}{c}\text { 60-month } \\
\text { formation } \\
\text { period }\end{array}$ \\
\cline { 2 - 7 } & EW & VW & EW & VW & EW & VW \\
\hline R & -0.31 & -0.17 & -0.33 & -0.22 & -0.20 & -0.02 \\
\hline & $(-1.10)$ & $(-0.48)$ & $(-1.19)$ & $(-0.62)$ & $(-0.70)$ & $(-0.04)$ \\
\hline$\alpha$ & -0.20 & -0.08 & -0.19 & -0.10 & -0.03 & 0.15 \\
\hline & $(-0.74)$ & $(-0.26)$ & $(-0.76)$ & $(-0.33)$ & $(-0.12)$ & $(0.47)$ \\
\hline
\end{tabular}

\begin{tabular}{|c|c|c|c|c|c|}
\hline \multicolumn{5}{|c|}{ Panel B: Payment type-stocks } \\
\hline $\begin{array}{c}\text { 36-month } \\
\text { formation } \\
\text { period }\end{array}$ & $\begin{array}{c}48 \text {-month } \\
\text { formation } \\
\text { period }\end{array}$ & $\begin{array}{c}\text { 60-month } \\
\text { formation } \\
\text { period }\end{array}$ \\
\hline EW & VW & EW & VW & EW & VW \\
\hline-0.34 & -0.12 & -0.29 & -0.06 & -0.28 & -0.24 \\
\hline$(-0.94)$ & $(-0.39)$ & $(-0.84)$ & $(-0.21)$ & $(-0.84)$ & $(-0.63)$ \\
\hline-0.33 & -0.05 & -0.22 & 0.02 & -0.18 & -0.11 \\
\hline$(-0.89)$ & $(-0.15)$ & $(-0.62)$ & $(0.06)$ & $(-0.53)$ & $(-0.36)$ \\
\hline
\end{tabular}

Note. The table reports mean monthly returns $(R)$ and intercepts $(\alpha)$ from the five-factor model of Fama and French (2015) of zero-investment calendar-time portfolios formed of stocks of firms that conducted acquisitions paid for with cash (Panel A) and stocks (Panel B) during the previous 36, 48, and 60 months. The portfolios go long (short) acquirers (other companies). $E W$ and $V W$ indicate equaland value-weighted portfolios. $R$ and $\alpha$ are expressed in percentage terms. The numbers in brackets are bootstrap (for $R$ ) and Newey-West (1987) adjusted (for $\alpha$ ) $t$-statistics. 
Again, no significant abnormal returns (raw or risk-adjusted) are observed in either the cash-paid or stock-paid cases. In other words, contrary to the apparent earlier theoretical and empirical evidence, the frontier market data confirm no notable underperformance of stock-paid deals. Again, this outcome also does not support the behavioral explanation of stock market acquisitions driven by relative mispricing between the acquirer and the target.

In addition to the reported tests, we conduct a few additional checks on the robustness of the time-series examinations. First, we split our main sample into cross sections based on three global regions: a) America, Asia, and the Pacific; b) Europe and Africa; and c) the Middle East. The regions are formed arbitrarily to provide a comparable number of firm-month observations within the subsamples. Subsequently, we conduct our standard time-series tests within the three geographical subsamples. We also supplement these examinations with a joint GRS test by Gibbons, Ross, and Shanken (1989) that verifies the hypothesis of whether all the intercepts from the five-factor model are equal to zero and equal to one other. The test is applied to a group of six portfolios, that is, the portfolios of acquirers and the portfolios of other stocks in each of the global regions. The six portfolios taken together form our full sample of frontier market companies.

Second, we divide the research period into two roughly equal subperiods: March 1997December 2006 and January 2007-September 2016. McLean and Pontiff (2016) documented that the profitability of equity anomalies tends to decline with time. Thus, we checked whether, perhaps, the negative abnormal returns were present in the earlier years, but later vanished.

Third, we take an alternative reference point in time to form portfolios. Instead of the completion date, we follow Loughran and Vijh (1997), DeLong (2003), and Zaremba and Plotnicki (2016), inter alia, and use the acquisition announcement date.

Table 3 displays the results of the additional robustness checks. The outcomes do not alter our basic conclusion that the acquirers do not underperform in frontier markets. The regional subsamples (Panel A, Table 3) revealed no significant negative returns, with the exception of equal-weighted portfolios of Middle Eastern stocks. Nonetheless, even in this case, when the more realistic value-weighting approach is used, the significant underperformance disappears and the joint GRS tests no longer confirm any abnormal returns. Also, the subperiod analysis (Panel B, Table 3, 4) disclosed no time-series variation in returns. The mean returns and alphas were equally indistinguishable from zero, both in earlier and later years. Finally, substituting the completion dates with the announcement dates for portfolio formation (Panel C, Table 3) did not lead to the appearance of any abnormal negative returns. Wrapping these observations up, the additional robustness checks do not support the mispricing theory of mergers; they document no robust abnormal returns on acquiring companies in frontier markets.

We performed also a few additional robustness checks. First, we additionally check the post-merger performance in the less and more efficient market segments. Second, we examine the influence of cross-sectionally varying limits on arbitrage and investor sentiment. These investigations reveal no qualitative differences in results. The detailed outcomes are reported in Appendices B and $\mathrm{C}$ to this article. 
Table 3. Additional robustness checks

Panel A. Geographical subsamples

\begin{tabular}{|c|c|c|c|c|c|c|}
\hline & \multicolumn{2}{|c|}{$\begin{array}{l}\text { 36-month formation } \\
\text { period }\end{array}$} & \multicolumn{2}{|c|}{$\begin{array}{l}\text { 48-month formation } \\
\text { period }\end{array}$} & \multicolumn{2}{|c|}{60 -month formation period } \\
\hline & EW & VW & EW & VW & EW & VW \\
\hline \multicolumn{7}{|c|}{ America, Asia, and the Pacific } \\
\hline \multirow[t]{2}{*}{$\mathrm{R}$} & 0.07 & -0.21 & 0.14 & -0.20 & 0.19 & -0.09 \\
\hline & $(0.20)$ & $(-0.44)$ & $(0.38)$ & $(-0.34)$ & $(0.51)$ & $(-0.15)$ \\
\hline \multirow[t]{2}{*}{$\alpha$} & 0.24 & -0.10 & 0.35 & -0.10 & 0.38 & 0.05 \\
\hline & $(0.69)$ & $(-0.25)$ & $(0.98)$ & $(-0.22)$ & $(1.16)$ & $(0.12)$ \\
\hline \multicolumn{7}{|c|}{ Europe and Africa } \\
\hline \multirow[t]{2}{*}{$\mathrm{R}$} & 0.18 & 0.08 & 0.18 & 0.07 & 0.20 & 0.03 \\
\hline & $(0.61)$ & $(0.27)$ & $(0.62)$ & $(0.25)$ & $(0.69)$ & $(0.10)$ \\
\hline \multirow[t]{2}{*}{$\alpha$} & 0.24 & 0.24 & 0.24 & 0.21 & 0.26 & 0.17 \\
\hline & $(1.04)$ & $(0.97)$ & $(1.05)$ & $(0.88)$ & $(1.14)$ & $(0.76)$ \\
\hline \multicolumn{7}{|c|}{ Middle East } \\
\hline \multirow[t]{2}{*}{$\mathrm{R}$} & $-0.58^{\star}$ & -0.16 & $-0.63^{*}$ & -0.32 & -0.46 & -0.16 \\
\hline & $(-2.44)$ & $(-0.37)$ & $(-2.57)$ & $(-0.85)$ & $(-1.74)$ & $(-0.39)$ \\
\hline \multirow[t]{2}{*}{$\alpha$} & $-0.52^{\star}$ & -0.06 & $-0.58^{\star}$ & -0.25 & -0.38 & -0.05 \\
\hline & $(-2.36)$ & $(-0.17)$ & $(-2.40)$ & $(-0.77)$ & $(-1.50)$ & $(-0.15)$ \\
\hline \multicolumn{7}{|c|}{ Aggregate statistics } \\
\hline GRS & $2.48^{\star}$ & 0.58 & $3.27^{\star \star}$ & 0.72 & $2.72^{\star}$ & 0.55 \\
\hline$p$-value & 0.0245 & 0.7484 & 0.0043 & 0.6355 & 0.0146 & 0.7672 \\
\hline
\end{tabular}

Panel B. Performance within subperiods

\begin{tabular}{|c|c|c|c|c|c|c|}
\hline & \multicolumn{2}{|c|}{$\begin{array}{l}\text { 36-month formation } \\
\text { period }\end{array}$} & \multicolumn{2}{|c|}{$\begin{array}{l}\text { 48-month formation } \\
\text { period }\end{array}$} & \multicolumn{2}{|c|}{ 60-month formation period } \\
\hline & EW & VW & EW & VW & EW & VW \\
\hline \multicolumn{7}{|c|}{ March 1997 - December 2006} \\
\hline \multirow[t]{2}{*}{$\mathrm{R}$} & 0.04 & 0.46 & -0.01 & 0.32 & 0.04 & 0.44 \\
\hline & $(0.13)$ & $(0.78)$ & $(0.03)$ & $(0.50)$ & $(0.13)$ & $(0.69)$ \\
\hline \multirow[t]{2}{*}{$\alpha$} & 0.02 & 0.47 & -0.02 & 0.33 & 0.03 & 0.46 \\
\hline & $(0.05)$ & $(0.89)$ & $(-0.05)$ & $(0.57)$ & $(0.07)$ & $(0.78)$ \\
\hline \multicolumn{7}{|c|}{ January 2007 - September 2016} \\
\hline \multirow[t]{2}{*}{$\mathrm{R}$} & -0.08 & -0.20 & -0.05 & -0.24 & 0.01 & -0.24 \\
\hline & $(-0.36)$ & $(-1.07)$ & $(-0.22)$ & $(-1.21)$ & $(-0.02)$ & $(-1.22)$ \\
\hline \multirow[t]{2}{*}{$\alpha$} & -0.17 & -0.11 & -0.08 & -0.17 & -0.03 & -0.21 \\
\hline & $(-1.11)$ & $(-0.61)$ & $(-0.57)$ & $(-1.17)$ & $(-0.20)$ & $(-1.16)$ \\
\hline
\end{tabular}


Panel C. Portfolios formed on announcement day

\begin{tabular}{|c|c|c|c|c|c|c|}
\hline & \multicolumn{2}{|c|}{$\begin{array}{l}\text { 36-month formation } \\
\text { period }\end{array}$} & \multicolumn{2}{|c|}{$\begin{array}{l}\text { 48-month formation } \\
\text { period }\end{array}$} & \multicolumn{2}{|c|}{$\begin{array}{l}\text { 60-month formation } \\
\text { period }\end{array}$} \\
\hline & EW & VW & EW & VW & EW & VW \\
\hline \multirow[t]{2}{*}{$\mathrm{R}$} & -0.09 & 0.08 & -0.11 & -0.03 & -0.07 & 0.03 \\
\hline & $(-0.35)$ & $(0.25)$ & $(-0.45)$ & $(-0.08)$ & $(-0.28)$ & $(0.10)$ \\
\hline \multirow[t]{2}{*}{ Int } & 0.04 & 0.19 & 0.03 & 0.11 & 0.08 & 0.19 \\
\hline & $(0.17)$ & $(0.83)$ & $(0.16)$ & $(0.46)$ & $(0.38)$ & $(0.79)$ \\
\hline
\end{tabular}

Note. The table reports mean monthly returns $(R)$ and intercepts $(\alpha)$ from the five-factor model of Fama and French (2015) of equal-weighed (EW) and value-weighted (VW) zero-investment calendar-time portfolios formed of stocks of firms that conducted acquisitions during the previous 36,48 , and 60 months. The portfolios go long (short) acquirers (other companies). The numbers in brackets are bootstrap (for $R$ ) and Newey-West (1987) adjusted (for $\alpha$ ) $t$-statistics. Asterisks * and ${ }^{* *}$ indicate statistical significance at the $5 \%$ and $1 \%$ levels, respectively. Panel A displays the performance within various geographical subsamples; Panel B reports the performance within subperiods; Panel C presents the returns on calendar-time portfolios formed on announcement day rather than completion date.

\section{Conclusions}

The present study examined the long-run performance of acquirers following M\&A deals. We analyzed almost 800 transactions within a sample of more than 3,600 stocks from 23 frontier markets for the years 1992-2016.

The primary results of this study could be summarized as follows. We detect no significant long-run abnormality in the returns of the acquirers, either when using cross-sectional or time-series tests. Furthermore, even though the theoretical basis implies that the effect should be more pronounced among the cash-paid transaction group and among the firms that are relatively small, illiquid, and characterized by considerable credit and idiosyncratic risk, additional robustness checks in the main manuscript and its appendices uncovered that this is not confirmed by the data; there are still no abnormal returns among these subgroups. Moreover, neither elevated investor sentiment nor excess market-wide limits on arbitrage are seen to strengthen the anomaly to a notable degree. Finally, the results are also robust to many considerations, including alternative reference points and formation periods, subsample, and subperiod. To sum up, our outcomes do not support the behavioral explanations of post-merger performance, including the hypothesis of Shleifer and Vishny (2003). The long-term underperformance observed among acquirers is likely to be a result of data snooping and an example of a spurious return pattern.

The results are important from both academic and practitioner's perspective. On the one hand, they provide new insights into asset pricing in international markets, casting doubt on the existence of abnormal post-merger returns. On the other hand, it has direct practical implications for money managers with local and international investment mandate: they should not be afraid of mergers because it is far from certain that they destroy value.

We are aware of some limitations of our research. Frontier markets are less recognized by investors, and we may not be aware of some special factors affecting our results. Our sample is also not homogeneous, and there might be local factors playing a role in some or all of 
the individual markets. We based our study on data denominated in U.S. dollars, whereas returns expressed in local currencies might have given a different picture of the situation seen through the eyes of local investors rather than global players.

Further studies on the issues discussed in this paper could be pursued in two major directions. First, it would be interesting to dig further to find potential reasons for the acquirers' different behavior in frontier markets as compared to mature ones. The possible explanations that we provided in this paper are only our speculative hypotheses that need to be examined further. Second, the identified lack of significant underperformance in frontier markets can be further investigated regarding potential differences in value creation in domestic and cross-border acquisitions.

\section{Acknowledgements}

We thank participants of the $5^{\text {th }}$ International Scientific Conference „Contemporary Issues in Business, Management and Education“ in Vilnius (Lithuania, 2017), the 2017 Global Finance Conference in New York (USA, 2017), and the $17^{\text {th }}$ Management International Conference in Venice (Italy, 2017) for their valuable insights and comments.

\section{Funding}

This work was supported by the National Science Centre of Poland [grant number 2013/09/B/ HS4/01335].

\section{References}

Agrawal, A.; Jaffe, J. F.; Mandelker, G. N. 1992. The post-merger performance of acquiring firms: a reexamination of an anomaly, Journal of Finance 47(4): 1605-1621. https://doi.org/10.1111/j.1540-6261.1992.tb04674.x

Andrade, G.; Mitchell, M.; Stafford, E. 2001. New evidence and perspectives on mergers, Journal of Economics Perspectives 15(2): 103-120. https://doi.org/10.1257/jep.15.2.103

Andre, P.; Kooli, M.; L'Her, J. 2004. The long-run performance of mergers and acquisitions: evidence from the Canadian stock market, Journal of Financial Management 33(4): 27-43.

Bouwman, C.; Fuller, K.; Nain, A. 2009. Market valuation and acquisition quality: empirical evidence, Review of Financial Studies 22(2): 633-679. https://doi.org/10.1093/rfs/hhm073

Casestudyinc. 2008. Daimler, Chrysler and the failed merger [online], [cited 10 October 2017]. Available from Internet: http://www.casestudyinc.com/daimler-chrysler-and-the-failed-merger

Dube, S.; Glascock, J. L. 2006. Effects of the method of payment and the mode of acquisition on performance and risk metrics, International Journal of Managerial Finance 2(3): 176-195. https://doi.org/10.1108/17439130610676466

Dutta, S.; Jog, V. 2009. The long-term performance of acquiring firms: a re-examination of an anomaly, Journal of Banking \& Finance 33(8): 1400-1412. https://doi.org/10.1016/j.jbankfin.2009.02.004

Fama, E. F. 1998. Market efficiency, long-term returns, and behavioral finance, Journal of Financial Economics 49(3): 283-306. https://doi.org/10.1016/S0304-405X(98)00026-9

Fama, E. F.; French, K. R. 2015. A five-factor asset pricing model, Journal of Financial Economics 116(1): 1-22. https://doi.org/10.1016/j.jfineco.2014.10.010 
Fama, E. F.; MacBeth, J. D. 1973. Risk, return and equilibrium: empirical tests, Journal of Political Economy 81(3): 607-636. https://doi.org/10.1086/260061

Franks, J.; Harris, R.; Titman, S. 1991. The postmerger share-price performance of acquiring firms, Journal of Financial Economics 29(1): 81-96. https://doi.org/10.1016/0304-405X(91)90014-B

Friedman, J. N. 2006. Stock market driven acquisitions: theory and evidence [online], [cited 10 October 2017]. Available from Internet: http://www.cirje.e.u-tokyo.ac.jp/research/workshops/macro/documents/JFriedman.pdf

Gallagher, P. 1998. Daimler Chrysler to ring Wall Street bell [online], [cited 10 October 2017]. Available from Internet: http://expressindia.indianexpress.com/fe/daily/19981117/32155024.html.

Gibbons, M. R.; Ross, S. A.; Shanken, J. 1989. A test of the efficiency of a given portfolio, Econometrica 57(5): 1121-1152. https://doi.org/10.2307/1913625

Harvey, C. R. 2017. The scientific outlook in financial economics. Presidential speech [online], [cited 10 October 2017]. Available from Internet: https://ssrn.com/abstract $=2895842$

Harvey, C. R.; Liu, Y.; Zhu, H. 2016. ... and the cross-section of expected returns, Review of Financial Studies 29(1): 5-68. https://doi.org/10.1093/rfs/hhv059

Isidore, C. 2007. Daimler pays to dump Chrysler [online], [cited 10 October 2017]. Available from Internet: http://money.cnn.com/2007/05/14/news/companies/chrysler_sale/?postversion=2007051408

Jensen, M.; Ruback, R. 1983. The market for corporate control: the scientific evidence, Journal of Financial Economics 11(1-4): 17-31. https://doi.org/10.1016/0304-405X(83)90004-1

Lau, B.; Proimos, A. 2010. The underperformance of equity-financed bidders, International Journal of Managerial Finance 6(1): 4-23. https://doi.org/10.1108/17439131011015760

Limmack, R. J. 1991. Corporate mergers and shareholder wealth effects: 1977-1986. Accounting and Business Research 21: 239-251. https://doi.org/10.1080/00014788.1991.9729838

Lin, H.-C.; Chou, T.-K.; Cheng, J.-C. 2011. Does market misvaluation drive post-acquisition underperformance in stock deals? International Review of Economics \& Finance 20(4): 690-706. https:// doi.org/10.1016/j.iref.2010.12.005

Loughran, T.; Vijh, A. 1997. Do long-term shareholders benefit from corporate acquisitions?, Journal of Finance 52(5): 1765-1790. https://doi.org/10.1111/j.1540-6261.1997.tb02741.x

Martin, L. R. 2016. M\&A: The one thing you need to get right. Harvard Business Review [online], [cited 10 October 2017]. Available from Internet: https://hbr.org/2016/06/ma-the-one-thing-youneed-to-get-right

McLean, D. R.; Pontiff, J. 2016. Does academic research destroy stock return predictability?, Journal of Finance 71(1): 5-32. https://doi.org/10.1111/jofi.12365

Mitchell, M. L.; Stafford, E. 2000. Managerial decisions and long-term stock price performance, Journal of Business 75(3): 287-329. https://doi.org/10.1086/209645

Moeller, S. B.; Schlingemann, F. P.; Stulz, R. M. 2005. Wealth destruction on a massive scale? A study of acquiring-firms returns in the recent merger wave, Journal of Finance 60(2): 757-782. https://doi.org/10.1111/j.1540-6261.2005.00745.x

Mueller, D. C. 1969. A theory of conglomerate mergers, Quarterly Journal of Economics 83(4): 643-659. https://doi.org/10.2307/1885454

Newey, W. K.; West, K. D. 1987. A simple positive-definite heteroskedasticity and autocorrelation consistent covariance matrix, Econometrica 55(3): 703-708. https://doi.org/10.2307/1913610

Rhodes-Kropf, M.; Viswanathan, S. 2004. Market valuation and merger waves, Journal of Finance 59(6): 2685-2718. https://doi.org/10.1111/j.1540-6261.2004.00713.x

Roll, R. 1986. The hubris hypothesis of corporate takeovers, Journal of Business 59(2): 197-216. https://doi.org/10.1086/296325 
Savor, P. G.; Lu, Q. 2009. Do stock mergers create value for acquirers? Journal Of Finance 64(3): 10611097. https://doi.org/10.1111/j.1540-6261.2009.01459.x

Shleifer, A.; Vishny, R. W. 1989. Managerial entrenchment: the case of manager-specific investments, Journal of Financial Economics 25(1): 123-139. https://doi.org/10.1016/0304-405X(89)90099-8

Shleifer, A.; Vishny, R. W. 2003. Stock market driven acquisitions, Journal of Financial Economics 70(3): 295-489. https://doi.org/10.1016/S0304-405X(03)00211-3

Sudarsanam, S.; Mahate, A. A. 2006. Are friendly acquisitions too bad for shareholders and managers? Long-term value creation and top management turnover in hostile and friendly acquirers, British Journal of Management 17(51): 7-30. https://doi.org/10.1111/j.1467-8551.2006.00476.x

Willenbrock, S. 2011. Diversification return, portfolio rebalancing, and the commodity return puzzle, Financial Analyst Journal 67(4): 42-49. https://doi.org/10.2469/faj.v67.n4.1

Zaremba, A.; Grobelny, P. 2016. Merger imbalance and returns in international equity markets, Investment Analysts Journal 46(2): 117-131. https://doi.org/10.2139/ssrn.2820587

Zaremba, A.; Płotnicki, M. 2016. Mergers and acquisitions: Evidence on post-announcement performance from CEE stock markets, Journal of Business Economics and Management 17(2): 251-266. https://doi.org/10.3846/16111699.2015.1104384 